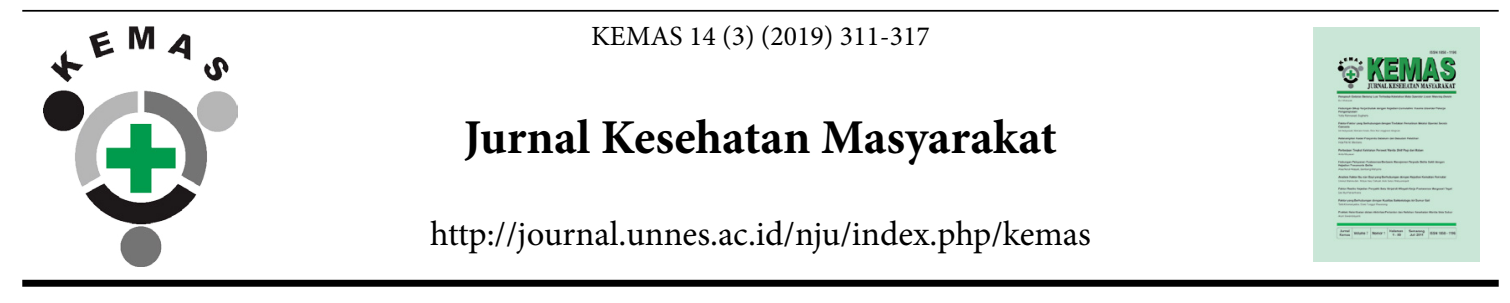

\title{
School Stakeholder's Support on the Use of Youth Information and Counseling Centers (PIK-R)
}

\author{
Khoiriyah Isni $^{1 \bowtie}$, Ratu Matahari ${ }^{1}$ \\ ${ }^{1}$ Faculty of Public Health, Universitas Ahmad Dahlan, Indonesia
}

\begin{tabular}{l} 
Article Info \\
\hline Article History: \\
Submitted October 2017 \\
Accepted July 2018 \\
Published March 2019 \\
\hline Keywords: \\
PIK-R Wijaya Kusuma, \\
SMAN 1 Srandakan, \\
stakeholder support \\
\hline DOI \\
https://doi.org/10.15294/ \\
kemas.v14i3.11699
\end{tabular}

\begin{abstract}
School stakeholder's support greatly affects PIK-R utilization by students. The problem is that school stakeholders are often only responsible but do not play an active role in PIK$\mathrm{R}$ implementation. The purpose of this study was to analyze the support of school stakeholders on the utilization of PIK-R Wijaya Kusuma SMAN 1 Srandakan. This research used qualitative research with case study approach. Key informants were principals, teachers PIK-R coach, guidance and counseling teachers, and peer counselors as triangulan. The data were collected through in-depth interviews. The results showed that the support of school stakeholders on the utilization of PIK-R wijaya kusuma was satisfactory. The support provided were in the form of active participation and involvement such as school counseling for students who experience problems, support in funding PIK-R activities, and cooperation efforts with other agencies. Some teachers were involved in health information socialization activities. Capacity building and skills related to adolescent health were also required by all teachers, so that all parties had the same understanding of PIK-R and gave full support to the utilization of PIK-R Wijaya Kusuma.
\end{abstract}

\section{Introduction}

Based on the theory by Willis in Anggraeni, adolescents are at the age of transition, where the individual has left a weak and dependent childhood, but has not reached a fully independent and responsible age, both to himself and the environment. A teenager is a child who has reached sexual maturity, but the level of mental and emotional maturity is still far behind (Anggraini, 2017). The momentum to bring adolescents and young adults to the center stage in global health and international development is palpable. Adolescents are increasingly seen as a crucial group for the success of the newly adopted Agenda for Sustainable Development. Sitting within the Agenda for Sustainable Development framework, the 2030 Global Strategy for
Women's, Children's and Adolescents' Health has extended the Every Woman, Every Child agenda to adolescence. The strategy articulates the need for adolescent-responsive health systems as well as social determinants, a focus that extends to legal and policy environments (Patton, 2016).

The low level of mental and emotional maturity of adolescents is influenced by their knowledge, especially on how to protect themselves against reproductive health risks, such as prevention of unwanted pregnancies, sexual transmitted infections and HIV / AIDS. The results of the teenage reproductive health surveys of 2013-2014 conducted by BPS show that the basic knowledge level of 15-24 years old about the characteristics of puberty is satisfactory, but in terms of knowledge about 
fertility and the risks of pregnancy, abortion, and anemia were insufficient. The results of Indonesia's adolescent reproductive health survey in 2013 stated that the reproductive health knowledge of adolescents aged 15-24 years was insufficient. Ministry of Health data in 2013 stated that utilization of healthcare services among Indonesian adolescent waslow, $50 \%$ or less active teenagers utilized adult reproductive health information consultation center as a consultation place on reproduction health (Stalker, 2008). Federal Medical Centre, Bida, and Federal Medical Centre, Yola. Data were analyzed using frequency tables and simple statistical methods. Results: One hundred and eighty-three doctors participated in the study, comprising 65 (35.5\%).

Lack of knowledge will have an impact on adolescent behavior. Some cases showed adolescents are easily affected to negative behaviors. Indonesian Family Planning Association of DIY in 2016 reported 443 cases of physical, psychological and sexual violence among adolescent girls aged 10-24 years. At the DIY Health Office, until November 2016, there were 720 teenagers who gave birth due to unwanted pregnancy reached 686 cases. The data is corroborated by data of marriage dispensation from the Religious Courts of Yogyakarta, reaching 340 applications in 2016 or increased from the previous year, which was 320 cases. Based on the phenomenon, it can be concluded that teenagers are not mature mentally and emotionally. Physiologically, adolescents experience rapid physical and hormonal growth, which further affects the emotional instability of adolescents (Priatini, 2008). The environment greatly affects the mental and emotional maturity of adolescents, including the school environment.

School is the second environment after family. The average junior and senior high school students spend about 7 hours a day at school. This means that one-third of the time is spent in school, hence the school is not only a place to gain knowledge, but also mould students' character. Many schools provide additional study hours or extracurricular activities.

SMA Negeri 1 Srandakan participated in preventing adolescent-related problems for their students, by creating an Information Center and Youth Counseling as one of the extracurricular activities in SMA Negeri 1 Srandakan. The goal is to help teenagers to obtain adequate information and counseling services about the preparation for family life (BKKBN, 2012).

PIK-R Wijaya Kusuma is an upright PIK-R line of schools owned by SMAN 1 Srandakan Bantul Regency. PIK-R Wijaya Kusuma succeeded to occupy the first winner of DIY Province in PIK-R / $\mathrm{M}$ competition organized by Family Welfare Board, Women's Empowerment and Family Planning and Bantul Regency Government in 2013 (Badan Kesejahteraan Keluarga, Pemberdayaan Perempuan dan Keluarga Berencana, 2013). The activities undertaken by PIK-R Wijaya Kusuma are not only counseling within the school's internal environment but also for adolescent groups outside the school. The implementation of the PIK-R school path is inseparable from the participation and support of all school residents, especially school stakeholders, such as principals and teachers. The role and support of school stakeholders are key determinants in the formation of PIK-R. Because PIK-R is formed by related parties such as principals and teachers, principals and teachers are included in the PIK-R determinant targets relating to PIK-R formation, development, service and coaching. There are various forms of principal's role in the implementation of PIK-R, including expectations, norms, actions, assessments, and sanctions (Nurvitasari, 2017).

The problem is when the role of school stakeholders only act as makers and decisionmakers while not understanding the entire the process of development and implementation of PIK-R activities. This can affect the sustainability of an organization if the decision-makers keeps playing a passive role. Therefore, it is necessary to study the role of school stakeholders in the utilization of PIK-R Wijaya Kusuma SMAN 1 Srandakan.

\section{Methods}

The was a qualitative research with case study approach. Research was conducted for 6 months (April-October 2017) at SMAN 1 Srandakan, Bantul. Keynote speakers in this research is the principal, while the 
triangulan was supervising teacher of PIK-R Wijaya Kusuma, and Counseling Guidance teachers. Peer counselor as triangulation. Data was collected through in-depth interview techniques based on in-depth interview guides. Data was analyzed using thematic data analysis, which is identifying patterned themes in a phenomenon.

\section{Result and Discussion}

This study aimed to determine the support of stakeholders to the utilization of PIK-R Wijaya Kusuma SMAN 1 Srandakan. Key informants in this study were principal, while the triangulan were teachers of PIK-R supervisor, counseling teacher, and peer counselor.

The success of education is determined by several factors; one of factors that contribute to successful learning and teaching at school is health and environment of the school. There are two processes in school, learning and educating the students. Learning is a process of interaction between students and teachers and with the source of learning, aimed to improve students' intelligence; whereas education is a process to develop students' capability and character. School is a formal and strategic institution to prepare human resources who are physically, mentally, and socially healthy to be productive human beings (Mahmudah, 2013).

When viewed from the perspective of WHO, analyze and add to the argument Green, there are four main factors and reasons to behave in certain ways. One is an important person as a reference; if someone is considered important to him, then what he said or do has a tendency to be emulated, for example teachers, clerics, doctors, parents. In this study, the presence of principals and teachers is a reinforcing factor for implementation of PIK-R activities.

The results stated that key informants followed the development of PIK-R Wijaya Kusuma since becoming a leader in the school in 2012. Furthermore, key informants sought the development of PIK-R in schools. This is as quoted from the following passage.

"Since 2012 developed, and I as
principal also supported and I
suggested for cooperation with various
agencies and for student activities program PIK-R wijaya kusuma as extracurricular program..."

(AB, Principal).

In addition, teachers and mentors were provided as supervisors of PIK-R activities. PIK-R activities have been around since 2012, but was not as developed as it is now. The rapid development of PIK-R Wijaya Kusuma can not be separated from the participation and support from the school. Support was provided in the form of cooperation with various other institutions, budget funding, budget funding from the Office of DIKPORA DIY, and organization of seminars that bring additional resources.

“..the school provided funding forextra
activities because PIK-R here become
the SMAN 1 Srandakan .... Starting
from 2015, I submitted to the office
of DIKPORA DIY, this school was
designated as a pre-eminent school in
PIK-R and received funding 8 million,
with tax deduction, our seminars
brought in speakers. For the year 2017,
this has not ....."
(AB, principal).

In addition, financial support is also provided by the school, although in a relatively small percentage. These small numbers can almost meet PIK-R operational activities.

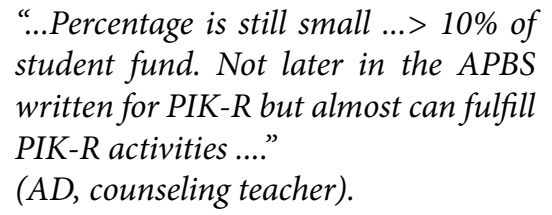

Funding support was not only provided for operational PIK-R activities, but also when one of the peer counselors passes the PIK-R contest to the national level and when there are activities outside the school. This is expressed by informants, such as the following statement:

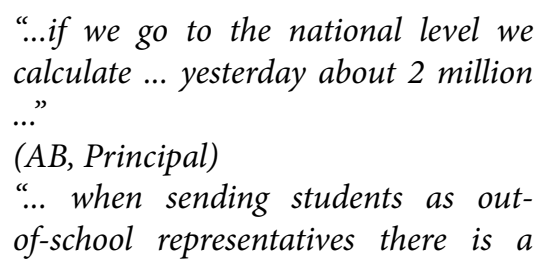


transport fee ....”

(AC, PIK-R Builder).

According to informants, support and funding for all information activities undertaken by PIK-R was known to all teachers in SMAN 1 Srandakan.

"...when we conduct activities, we involve all teachers (for the unreached)" (AC, PIK-R coach).

Complete support provided by the school was felt to be different by one of the PIK-R activists. The informants felt that school support was only 50 percent. Informants are well aware that if there is no support from the school, it will affect the sustainability of a school organization.

“...really support but only $50 \%$. the $50 \%$ is almost gone too. If the organization's name, if the school does not support it will also affect ..."

(AE, Peer Counselor).

Peer counselor informants felt that support should be given fully by all parties, not only by certain teachers, whereas other teachers only supported as necessary. However, this was not in line with what the informant told us as a teacher of counseling.

".... There are socialization from outside parties that we involved in order for some teachers to obtain information ..." ( $A D$, teacher counseling).

Other supporting factors are found from in-depth interviews with the principal is the existence of external support. External support was school collaboration with other institutions that support PIK-R activities, including from the formal, informal and educational sectors.

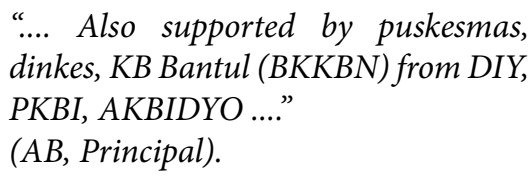

An organization's implementation is inseparable from supporting and inhibiting factors. The results revealed that the characteristics and activities of students per year was perceived to be one of the inhibiting factors in the development of PIK-R activities. Nevertheless, with various support from internal and external parties, PIK-R Wijaya Kusuma keeps running and obtain achievements. Another study mentioned that the decreasing PIK-R decreases from the implementation of activities that do not meet expectations. For example, activities in the field are lacking, lack of seriousness in providing counseling, lack of enthusiasm in the attending meetings, regeneration of administrators and management of PIK-Teen Administration. So PIK-R has not been able to help solve the problem of teenagers in North Semarang (Fitriani, 2016)

Support from both internal and external parties provided a positive expectation on the continuity of activities and achievements of PIK-R Wijaya Kusuma. One hope is to make PIK-R a compulsory extracurricular activity for students, just like scouts. So that all students have equal opportunity to follow and obtain health information, and receive skill training of adolescent life, not only students will be the members of PIK-R. If PIK-R activities become mandatory extracurricular activities, the students' exclusivity and in-student gaps are unlikely to be found in an activity that has achieved much achievement such as PIK-R Wijaya Kusuma. Another study revealed that student participation in assessing the needs and prioritizing problems in real conditions depended on the performance of good counseling services. Counselor empowerment, planning, monitoring and evaluation of counseling are indispensable for better outcome (Peykari et al., 2011).

“.... not yet ... it's good, for the future to consider. Must be coordinated with school leaders, teachers and employees .... "(AB, Principal).

In accordance with the National HIV and AIDS Control Strategy for Children and Adolescents in 2007-2010, HIV infection prevention programs for children and adolescents need to increase and provide true and updated information about HIV-AIDS 
and drugs to adolescents through mass media and other appropriate means for adolescents, improvement and extension of life skills to children and adolescents inside and outside schools, and integration of sexual health and reproductive health into the school curriculum (BKKBN, 2012).

In general, it can be said that school stakeholders supported PIK-R activities, although not yet fully. At least, activities that support PIK-R development and improvement of students' knowledge and skills, continue to be conducted by school stakeholders. One of the school stakeholders who is also the highest decision maker for all forms of PIK-R activities is the principal. The position of the principal in an organization is the leader. Without the presence of leaders, educational processes, including learning, will not be effective. Education will become uncoordinated, both by the teachers, staff and students. Educational institutions without a leader will not be held task, function, and responsibilities of the principal (Hermino, 2015).

All principals should be knowledgeable, skilled, dedicated and risk takers. They have to modify curriculum for the ultimate realization of the academic goals. The principals should implement their academic roles in the dimensions of their managerial premise and achieve the curricular targets. The job of a principal is quite demanding and challenging, especially in the context of educational development and institutional effectiveness. Each day affords a rare wealth of experience and opportunities for creative thinking and discovering plausible solutions to the problems. It is necessary for the principal to involve staff members and student representatives to seek and suggest solutions to problemsThis would mould staff members' and students' behavior (Khan, 2014). Therefore, the school principal's role in all processes that occur within the school is of utmost importance, especially regarding HIV / AIDS prevention efforts at schools in PIK-R activities

The school principal's decision to establish PIK-R in a school environment that is currently being developed requires facility and support from other parties, ie facilities from the school, such as a room for PIK-R members to gather and discuss issues discussions. In addition, PIK-R members can socialize by going around to classes to provide peer counseling, as well as support from other parties, namely guidance and counseling teachers, who have attended training and counseling from relevant agencies in the provision of materials and as a supervisor of PIK-R activities already established in schools (Nurvitasari, 2017).

The results of this study indicated that in addition to the principal, teachers were the second largest supporting factor in the implementation of PIK-R Wijaya Kusuma activities. The guidance and development of PIK-R activities was conducted based on guidance and approval from teachers of the PIK-R. Apart from being supervisers, teachers were also a source of health information. information was delivered in the classroom while delivering the subject matter appropriate to adolescent health problems, such as physical education and sports, biology, and religion. In addition to these functions, teachers were also a source of personal advice for students. In line with this study, teachers felt more comfortable to provide school-based reproductive health information in the form of personal counseling rather than during class (Aransiola et al., 2013). Another study mentions that teachers were more interested in engaging in promoting reproductive health to students than contraception usage counseling (Iyaniwura, 2004). However, Doctors, health workers, or experts are still needed to provide correct scientific information to adolescents regarding reproductive health by incorporating Reproductive Health Education in school curriculum (Borkar, 2017).

Another important point of PIK-R is peer counseling. Peer counseling is an interactive relationship within age groups aimed at promoting positive behavior change. The peers discus their problems amicably without getting involved in bad behavior and consequently improve their academic performance (Bett, 2013). The role of peer counselor are as preventive that helps clients maintain or prevent the occurrence of problems and curative/corrective action to help their clients to solve the problem at hand. Counseling model for teenage should have an 
easy procedure, complete services, appropriate opening hours, no discrimination, respect for privacy, provide prochoice, and low price. In fact, it is not easy to build a reproductive health service that is easily accessible to teenagers. The problems encountered include lack of adolescent-friendly medical staff, lack of funds to create an ideal service, and barriers of value from the surrounding community due to their cultural construction (Nugroho, 2017). This is a challenge for schools, how to develop that is favored by adolescent students. School organizations are in the frontline in improving the welfare and health of individuals and community, and is a reflection of a complete society, because they consist of components such as teachers, headmaster, students, employees and others who are also a part of a larger society. Health should be accessible globally so that it can provide comprehensive healthcare for all (Ooms, 2014). This is possible with the responsibility and full support of school stakeholders.

Efforts made by school stakeholders in the development, coaching and implementation of PIK-R activities can be said to be good. This is demonstrated by the funding support for PIK-R operational activities from the APBS budget, the funding of the PIK-R race delegates and the school, district, provincial and national level peer counselors. Then, the effort and cooperation with various related agencies, as well as involvement of nearly all teachers in the socialization activities and delivery of adolescent health information. The inhibiting factors identified in this study include variation in active student participation. However, achievement was still needed in order to participate in various PIK-R competitions up to national level. In addition, not all teachers care about PIK-R activities, hence the perception of inoptimal support from the school. Seeing that stakeholder support for the implementation of PIK-R activities is correlated with achievements, if not matched by the full involvement of all elements of the school, it is feared that sustainability will be difficult. Hence implementation, capacity building and skills were not only demanded from PIK-R members but also teachers at SMAN 1 Srandakan. Hopefully, this will further enhance the sense of belonging so that support does not only come from above, but also from below, in this case from teachers and students. To initiate this, the active role and support from stakeholders is necessary.

\section{Conclusion}

Support provided by school stakeholders on PIK-R activities Wijaya Kusuma SMAN 1 Srandakan can be said to be satisfactory. School stakeholders in this study were principals, teachers/supervisors of PIK-R and guidance and counseling teachers. The form of support is the involvement and active participation of stakeholders in PIK-R activities. In addition, funding support for PIK-R activities, sending delegates to peer competitions or counselors, collaboration with other agencies from the formal, informal and higher education sectors as well as the involvement of all teachers in the socialization and delivery of adolescent health materials.

\section{References}

Anggraini, Yuliza., 2017. Hubungan Fungsi Afektif Keluarga dengan Perilaku Kenakalan Remaja di SMK Cendana Padang Panjang Tahun 2016. Menara Ilmu, XI(76), pp. 155-165.

Aransiola, J.O., Asa, Sola., Obinjuwa, P., Olarewaju, O., Ojo, O.O., Fatusi, A.O., 2013. Teachers' Perspectives on Sexual and Reproductive Health Interventions for In-school Adolescents in Nigeria. African Journal of Reproductive Health, 17(4), pp. 84-92.

Badan Kesejahteraan Keluarga, Pemberdayaan Perempuan dan Keluarga Berencana., 2013. PIK R "Wijaya Kusuma" SMA N I Srandakan Juara I DIY. Bantul: Badan Kesejahteraan Keluarga, Pemberdayaan Perempuan dan Keluarga Berencana.

Bett, J.C., 2013. The Importance of Promoting the Value and the Role of Peer Counseling among Students in Secondary Schools. International Journal of Economy, Management and Social Sciences, 2(6), pp. 477-484.

BKKBN.,2012.Pedoman Pengelolaan Pusat Informasi dan Konseling Remaja dan Mahasiswa (PIK $R / M)$. Jakarta: Badan Kependudukan dan Keluarga Berencana Nasional.

Borkar, R.S., Patil, C.G., Meshram, S.A., 2017. Attitude of Adolescent School Students Towards Reproductive Health Education. International Journal of Community Medicine and Public Health, 2(4), pp. 484-488.

Fitriani, I.N., 2016. Pengembangan Metode Pelatihan dengan Problem Card Dalam 
Peningkatan Pengetahuan dan Sikap Remaja tentang Kesehatan Reproduksi. Journal of Health Education, 1(1), pp. 21-25.

Hermino, A., 2015. Pendidikan Karakter dalam Perspektif Psikologis Siswa Sekolah Menengah Pertama di Era Globalisasi dan Multikultural. Jurnal Peradaban, 8, pp. 1940.

Iyaniwura, C.A., 2004. Attitude of Teachers to School based Adolescent Reproductive Health Interventions. Journal of Community Medicine \& Primary Health Care, 16(1), pp. 4-9.

Khan, A.N., \& Khan, I.A., 2014. Academic Role of a Principal and Continuous Professional Development. Journal of Education and Human Development, 3(2), pp. 925-942.

Mahmudah, U., Cahyati, W.H., Wahyuningsih, A.S., 2013. School Health Development Index (SDHI) as an Instrument for School Health Development. Jurnal Kesehatan Masyarakat, 8(2), pp. 113-120.

Nugroho, E., Shaluhiyah, Z., Purnami, C.T., Kristawansari., 2017. Counseling Model Development Based on Analysis of Unwanted Pregnancy Case in Teenagers. Jurnal Kesehatan Masyarakat, 13(1), pp. 137-144.

Nurvitasari, H., Ririanty, M., Nafikadini, I., 2017. Peran Kepala Sekolah Tingkat SMA terhadap Pembentukan Pusat Informasi dan Konseling Remaja dalam Upaya Pencegahan HIV-
AIDS (Studi Kualitatif pada SMA Kabupaten Jember). Artikel Ilmiah Hasil Penelitian Mahasiswa. Bagian Promosi Kesehatan dan Ilmu Perilaku. Fakultas Kesehatan Masyarakat. Universitas Jember.

Ooms, G., Marten, R., Waris, A., Hammonds, R., Mulumba, M., Friedman, EA., 2014. Great expectations for the World Health Organization: A Framework Convention on Global Health to Achieve Universal Health Coverage. Public Health Journal, 128(2), pp. 173-8.

Patton, G., Temmerman, M., 2016. Evidence and Evidence Gaps in Adolescent Health. Journal of Adolescent Health, 59(2), pp. S1-S3.

Peykari, N., Tehrani, F.R., Afzali, H.M., Eftekhari, M.B., Djalalinia, S., 2011. The Key Stakeholders' Opinions Regarding University Counseling Centers:an Experience from Iran. Journal of Research in Medical Sciences, 16(9), pp. 1202-1209.

Priatini, W., Latifah, M., Guhardja, S., 2008. Pengaruh Tipe Pengasuhan, Lingkungan Sekolah, dan Peran Teman Sebaya terhadap Kecerdasan Emosional Remaja. Jurnal Ilmu Keluarga Dan Konsumen, 1(1), pp. 43.

Stalker, P., 2008. Millenium Development Goal. Nigerian Journal of Clinical Practice, 14(3), pp. 318-321. 